\title{
INSTITUTIONAL OWNERSHIP CAPABILITY IN MODERATED DISCLOSURE EFFECT OF ENTERPRISE RISK MANAGEMENT, INTELLECTUAL CAPITAL, AND CORPORATE SOCIAL RESPONSIBILITY ON FIRM VALUE
}

\author{
Mahindrayogi Komang Trisdia*, Badera I Dewa Nyoman \\ Master's Program of Accounting, Faculty of Economics and Business, \\ Udayana University, Indonesia \\ *E-mail: mahindrayogi@gmail.com
}

\begin{abstract}
This study aims to obtain empirical evidence of institutional ownership capability in moderated the effect on firm value. Population on this study are banking companies sector that listed in Indonesia Stock Exchange for 2012-23016. Non probability sampling use in this study as a sampling technique with purposive sampling method and get 30 companies as sample of this research. The results of empirical evidence showing that high value of institutional ownership able to strengthen the effect of intellectual capital disclosure on firm value.
\end{abstract}

\section{KEY WORDS}

Enterprise, risk, management, intellectual capital, corporate social responsibility, institutional ownership, firm value.

A company is basically established with the aim to optimize the owner's prosperity. The owner's prosperity can be seen from the high value of the company as reflected by the company's stock price (Devi et al., 2016). Investors will know the value of a company from information disclosed to public. Signaling theory states that investors and other stakeholders will use the information released by the company in helping them to make decisions (Jogiyanto, 2000). Hoyt et al. (2008) states that company value can be improved and maintained through the disclosure of information that published by the company both financial and non financial disclosure. In Indonesia the concern about the value of the company has become very important especially in the banking industry, because banks as financial institutions are considered to have high business complexity and are highly vulnerable to risks primarily because it involves the management of public funds (Maulani and Rahayu, 2015).

The phenomenon that occurs related to the value of the company in the banking sector can be seen from the decline in stock prices of Bank International Indonesia (BII) in 2012 and Bank Mega in April 2011 (Kompas.com, May 3, 2011). From both cases, it can be seen that there is an indication of the lack of attention to risk management by Bank International Indonesia (BII) and Bank Mega especially on internal environmental control because both cases are done on cooperation among company employees.

Implementation of risk management becomes very important to do because by implementing ERM will be able to reduce the potential losses that occur in the company (Bertinetti et al., 2013). Hoyt and Lienbenberg (2011) explain that the disclosure of ERM as one of the non-financial information disclosure in a company will provide additional benefits and information for investors. Wider disclosure of ERM will increase investor confidence and will affect the value of a company (Beasley et al., 2008).

Attention to the knowledge of human resources owned by a company is also very important thing in the modern business as today (Widarjo, 2011). The awareness that knowledge-based businesses become an important role for corporate growth will make an attention to intellectual capital (IC) disclosure (Wang et al., 2014). Bontis et al. (2001) defines IC as the knowledge ownership of an organization that contributes to enhancing the competitive position by adding value to those with interests. The information contained in IC 
disclosure can be utilized by investors to assist them in making predictions and assessing the company's ability to create wealth in the future (Bukh et al., 2005).

Disclosure of information about corporate responsibility to society and the social environment is also a matter of concern. The success of a business entity is not only seen from the increase in profits but also influenced by how the contribution to the welfare of society and the surrounding environment (Jo and Harjoto, 2011). The form of corporate responsibility in social and environmental aspects is realized by running a Corporate Social Responsibility (CSR) program. CSR is a form of commitment and cooperation between employees, local communities, and communities to contribute to sustainable economic development (Servaes and Tamayo, 2013). Disclosure of CSR is one of the factors affecting corporate value because CSR is seen as a goodwill of the company with responsibility for society and its social environment (Chetty et al., 2015).

However, there are also some inconsistent results of previous studies on the relationship between ERM, IC, and CSR disclosures on firm value. Mulyasari et al. (2016) found no influence between ERM disclosure to firm value. This is supported by research conducted by Agustina and Baroroh (2016) and research conducted by Aditya and Naomi (2017). Sunarsih and Mendra (2012) found no effect of IC on firm value. Research conducted by Wibowo et al. (2016) produces empirical evidence that CSR disclosure negatively affects firm value. The inconsistency of the research results prompted the author to add institutional ownership as a moderating variable. Institutional ownership is chosen as a moderating variable because with a high degree of institutional ownership it can reduce agency problems, especially in controlling opportunistic behavior of management (Sari et al., 2013).

\section{LITERATURE REVIEW}

Signaling Theory. Signaling theory has a strong association with the availability of information. Jogiyanto (2000) states that information published to the public as an announcement will provide a signal to users of financial information in decision making. User information, especially investors will interpret and analyze the information as a good news or bad news. One type of information issued by a company that can be a signal for parties outside the company is annual report (Tahir and Razali, 2011). The information disclosed in annual report can be financial information that is information relating to financial statements and nonfinancial information that is information that is not related to the financial statements. Non-financial information that should be disclosed by banking companies are ERM and CSR. Voluntary disclosure is an attempt by management to provide private information to potential investors in the hope of becoming good news for the company. One form of voluntary disclosure that can be good news for users of information is the disclosure of IC which is expected to increase the value of the company.

Agency Theory. The agency relationship is a contract whereby one or more persons (principal) asks the other as an agent to carry out some work that involving the delegation of some authorities (Jensen and Meckling, 1976). Agency theory explained that there is a conflict between agent and principal. Contractual relationships between company owners and management will be difficult to create due to conflicting interests (conflict of interest). Both parties, principals and agents involved in the contract will try to maximize the utility they have. The conflicts that occur are caused by the asymmetry of information that the agent has more information that is used to maximize its utility when compared with the principal. Institutional ownership is believed to reduce management behavior for opportunistic acts. The higher the institutional ownership in the company, the more effective the monitoring to reduce the conflict. Management will be increasingly compelled to disclose information in a timely manner to avoid diminishing the relevance of available information. The information presented should be understandable, reliable, relevant, and transparent because the information is used as a basis for decision-making for interested parties (Amran et al., 2009).

The Capability of Institutional Owners Moderates the Influence of ERM Disclosure on Corporate Value. Prayoga and Almilia (2013) in their research stated that ownership structure is considered to improve the quality of risk management within a company. With the 
ownership of the institution as a form of ownership structure in a company, shareholders will have a strong preference to control the action and improve supervision on the performance of management so that the demand by the shareholders about the identification of risks that may be faced by the company will increase. Disclosure of risk management practices undertaken by management can improve the image of the company to be viewed favorably by all stakeholders (Agista and Mimba, 2017). It will be reflected in the company's higher stock price, thus indicating the company's increasing value.

H1. Institutional ownership moderates positively the impact of ERM disclosure on firm value.

The Capability of Institutional Owners Moderates the Effect of IC Disclosure on Corporate Value. Ali et al. (2007) found that institutional ownership can improve the quality and quantity of voluntary disclosure. Disclosure of the IC is one of the voluntary disclosures committed by the company. Voluntary disclosure done by a company will create added value so as to increase the competitive advantage in the long term. Institutional ownership is an important oversight mechanism in minimizing agency conflicts that occur between company owners and managers. The greater the ownership by the institution, the greater the power of voice and the drive to optimize the value of the company. In other words, companies with a high degree of institutional ownership will attempt to express intellectual capital more broadly and more comprehensively than firms with low institutional ownership levels in order to increase company value (Febriana and Nugrahanti, 2013).

H2. Institutional ownership moderates positively the influence of IC disclosure on firm value.

The Capability of Institutional Owners Moderates the Influence of CSR Disclosure on Corporate Value. Agency theory states that the separation between ownership and management of a company can lead to agency conflicts caused by principals and agents having different and conflicting interests so that both the agent and principal will equally seek to maximize the utility it has. Therefore, it needs a control mechanism from management performance so as not to behave opportunistic. One such mechanism is the existence of institutional ownership. The control mechanism of institutional ownership can encourage a company to pay more attention to its social and environmental responsibilities. The better the performance of the company in improving the environment then the value of the company will increase. This is supported by research conducted (Sari et al., 2013) stating that institutional ownership positively affects CSR disclosure.

H3. Institutional ownership moderates positively the influence of CSR disclosure on firm value.

\section{METHODS OF RESEARCH}

This research was conducted in banking companies for the period 2012-2016 listed in Indonesia Stock Exchange (BEI). The reason for choosing the period of research from 20122016 period is because in 2011 there was a phenomenon in banking companies that affect the company's stock price which one of the causes is due to lack of attention to enterprise risk management. The sample in this research are 30 companies. The criteria considered in the sampling of this research are banking companies registered consecutively during the observation period that is from 2012-2016.

Data analysis used in this research includes classical assumption test and moderated regression analysis (MRA) test. MRA is an application, especially multiple linear regression where in the regression equation stems the interaction elements (multiplication of two or more independent variables) (Liana, 2009).

Operationalization of Variables. In this study, the dependent variable is corporate value. Corporate value is a market value that can provide maximum shareholder wealth if the company's stock price increases. The corporate value in this study is proxied using Tobin's $Q$

Independent variables in this research are the disclosure of ERM, IC, and CSR. ERM disclosure is a form of disclosure of the implementation and management of corporate risk that has been managed to minimize uncertainty and maximize opportunities to achieve 
corporate goals. ERM calculations in this study use ERM Framework created by COSO where there are 108 items of disclosure. The calculation of ERM disclosure items uses a dichotomous approach, where each item of ERM disclosure is disclosed given value 1 and value 0 if not disclosed (Meizaroh and Lucyanda, 2011).

IC disclosure is the level of disclosure of intellectual capital owned by a company (Bontis et al., 2001). The disclosure index used in this study is the index of intellectual capital disclosure used by Singh and Zahn (2007). This index consists of 81 items of disclosure. The calculation of disclosure items on the IC using the dichotomy approach, each disclosed item of disclosed IC is given a value of 1 and a value of 0 if not disclosed.

CSR disclosure is the disclosure of information on corporate social responsibility in the annual report as measured by Corporate Social Responsibility Index (CSRI). The CSR measurement instrument used in this study was based on Global Reporting Initiatives Generation 3.1 (GRI G3.1) with 84 items of disclosure. Each CSR item in a research instrument is assigned a value of 1 if it exists and a value of 0 if does not exist.

The moderating variables in this study is institutional ownership as the variables that influence (strengthen or weaken) the relationship between independent variables with dependent. Institutional ownership is the ownership of shares of an enterprise by institutions such as cooperatives, banks, pension funds, and others. A high degree of institutional ownership will lead to a larger oversight effort that is expected to reduce opportunistic behavior on the part of management. The institutional ownership in this study is the percentage of ownership owned by the institution (Sari et al., 2013).

\section{RESULTS AND DISCUSSION}

Sample Description. The population in this study is the banking sector companies listed on the BEl during the period 2012 to 2016. The sample used in this study selected by purposive sampling based on predefined criteria so that the sample used can represent the existing population so that in accordance with the purpose of the study. The results of the research sample selection are shown in Table 1.

Table 1 - Sample Selection Process

\begin{tabular}{|c|c|c|}
\hline No & Criteria & $\begin{array}{c}\text { Number } \\
\text { of Companies }\end{array}$ \\
\hline 1 & Banking companies listed on the Indonesia Stock Exchange during the period 2012-2016. & 43 \\
\hline \multirow[t]{4}{*}{2} & $\begin{array}{l}\text { Banking companies that are not listed in a row on the Indonesia Stock Exchange during the } \\
\text { period } 2012-2016 \text {. }\end{array}$ & (13) \\
\hline & Number of Final Samples & 30 \\
\hline & Year of Observation & 5 \\
\hline & Number of Observations & 150 \\
\hline
\end{tabular}

Source: data processed (2018).

Table 1 shows that based on predetermined criteria, 30 companies were selected to be sampled with a five-years observation period, resulting in a total of 150 observations.

Descriptive Statistics Analysis. Descriptive statistics are used to provide descriptions and descriptions of data from all variables in the study. The results of descriptive statistical tests are presented in Table 2.

Table 2 - Descriptive Statistics Results

\begin{tabular}{llllll}
\hline Variable & $\mathrm{N}$ & Minimum & Maximum & Average & Std. Deviation \\
\hline $\mathrm{NP}(\mathrm{Y})$ & 150 & $-0,05$ & 0,86 & 0,1 & 0,16 \\
$\mathrm{ERM}\left(\mathrm{X}_{1}\right)$ & 150 & 0,35 & 0,91 & 0,6 & 0,14 \\
$\mathrm{IC}\left(\mathrm{X}_{2}\right)$ & 150 & 0,17 & 0,77 & 0,46 & 0,15 \\
$\mathrm{CSR}\left(\mathrm{X}_{3}\right)$ & 150 & 0,15 & 0,49 & 0,31 & 0,07 \\
KI $\left(\mathrm{X}_{4}\right)$ & 150 & 25,91 & 99 & 73,31 & 17,56 \\
Valid N (listwise) & 150 & & & & \\
\hline
\end{tabular}

Source: data processed (2018). 
Based on Table 2 it can be explained that the firm value variable proxied by using Tobin's $Q$ has an average value of 0.10 ; with the highest score of 0.86 ; the lowest value of 0.05 ; and with a standard deviation value of 0.16 . A larger standard deviation value compared to the average indicates that the value of firms in the banking companies listed on the IDX has large fluctuations. Descriptive analysis results show that the minimum value of the value of the company has a negative value indicating that there is a banking sector company whose assets are rated very low by the market.

The ERM disclosure variables proxied using the ERM disclosure index have an average value of 0.60 . The highest value of ERM disclosure is 0.91 ; while the lowest value is 0.35 ; with a standard deviation value of 0.14 . A smaller standard deviation value compared to the average indicates that the ERM disclosure in the banking companies listed on the IDX has small fluctuations.

The IC disclosure variables proxied by using the IC disclosure index have an average of 0.46 . The highest value of IC disclosure is 0.77 ; while the lowest value is 0.17 ; with a standard deviation value of 0.15 . A smaller standard deviation value compared to the average indicates that IC disclosure in a banking company listed on the IDX has small fluctuations.

The CSR disclosure variables proxied using the CSR disclosure index have an average of 0.31 . The highest value of CSR disclosure is 0.49 ; while the lowest value is 0.15 ; with a standard deviation value of 0.07 . A smaller standard deviation value compared to the average indicates that CSR disclosure to a banking company listed on the IDX has small fluctuations.

The institutional ownership variable (X4) has the lowest value of 25.91; highest score of 99.00; average of 73.32 and has a standard deviation of 17.56. The average value of 73.32 closer to the 99.00 high indicates that the institutional shareholding of 150 companies is greater than that of the management.

Normality test. Normality test in this study using Kolmogorov-Smirnov test. The normality test results from this study are presented in Table 3 below.

Table 3 - Normality Test Results

\begin{tabular}{ll}
\hline & Unstandardized Residual \\
\hline $\mathrm{N}$ & 150 \\
Kolmogorov-Smirnov Z & 1,06 \\
Asymp. Sig. (2-tailed) & 0,21 \\
\hline
\end{tabular}

Source: data processed (2018).

Research data is said to be normal distribution if Asymp value. Sig. (2-tailed) is greater than $\alpha=5 \%$ or 0.05 . Based on Table 5.3 above Asymp value. Sig. (2-tailed) model of the equation tested of 0.21 is greater than $\alpha=5 \%$ or 0.05 . This shows the residual data from the regression model in this study is normally distributed.

Heteroscedasticity Test. The heteroscedasticity test was performed to test whether in the regression model there was a variance inequality of the residual one observation to another observation (Ghozali, 2016). The test used in this research is Glejser test. If the level of significance of each independent variable is greater than 0.05 then it is concluded that there is no heteroscedasticity. The results of heteroscedasticity test are shown in Table 4.

Table 4 - Heteroscedasticity Test Results

\begin{tabular}{ll}
\hline Variable & Significance \\
\hline ERM & 0,80 \\
IC & 0,92 \\
CSR & 0,99 \\
KI & 0,52 \\
ERM*KI & 0,70 \\
IC*KI & 0,35 \\
CSR $^{*} \mathrm{KI}$ & 0,36 \\
\hline
\end{tabular}

Source: data processed (2018). 
Based on Table 4 it is known that all independent variables in the regression model have a significance value greater than 0.05 so it can be concluded that the regression model of this study is free from symptoms of heteroscedasticity.

Autocorrelation Test. The autocorrelation test aims to test whether in a regression model there is a correlation between the confounding error in the previous $\mathrm{t}-1$ period (Ghozali, 2016). The autocorrelation test in this research was conducted by Durbin-Watson test (DW test). The results of the autocorrelation test are shown in Table 5.

Table 5 - Autocorrelation Test Results

\begin{tabular}{cccccc}
\hline Model & $\mathrm{R}$ & $\mathrm{R}$ Square & Adjusted R Square & Std. Error of the Estimate & Durbin-Watson \\
\hline 1 & 0,55 & 0,29 & 0,27 & 0,14 & 1,989 \\
\hline
\end{tabular}

Source: data processed (2018).

The autocorrelation test results showed that the regression model used in the study did not have autocorrelation, which is seen from the Durbin-Watson value of 1.989 with $n=150$ and $\mathrm{k}=4$ shows the $\mathrm{dU}<\mathrm{d}<4-\mathrm{dU}$ value of $1.788<1.989<2.212$. This value indicates there is no positive or negative autocorrelation in the regression model. This indicates that the research regression model is free from autocorrelation

Based on the results of the data with the help of SPSS, then obtained the results presented in Table 6 below.

Table 6 - Regression Test Results

\begin{tabular}{|c|c|c|c|c|c|}
\hline \multirow{2}{*}{ Variable } & \multicolumn{2}{|c|}{ Unstandardized Coefficients } & Standardized Coefficients & \multirow[t]{2}{*}{$\mathrm{T}$} & \multirow[t]{2}{*}{ Sig } \\
\hline & $\mathrm{B}$ & Std. Error & Beta & & \\
\hline (Constant) & 0,10 & 0,09 & & 1,21 & 0,23 \\
\hline $\operatorname{ERM}\left(X_{1}\right)$ & 0,08 & 0,01 & 0,49 & 5,99 & 0,00 \\
\hline $\mathrm{IC}\left(\mathrm{X}_{2}\right)$ & 0,06 & 0,01 & 0,31 & 4,36 & 0,00 \\
\hline $\operatorname{CSR}\left(X_{3}\right)$ & 0,04 & 0,01 & 0,21 & 2,93 & 0,00 \\
\hline $\mathrm{KI}\left(\mathrm{X}_{4}\right)$ & 0,00 & 0,00 & 0,07 & 0,97 & 0,37 \\
\hline $\mathrm{ERM}{ }^{*} \mathrm{KI}\left(\mathrm{X}_{1}{ }^{*} \mathrm{X}_{4}\right)$ & 0,00 & 0,00 & 0,05 & 0,63 & 0,53 \\
\hline$I C^{*} \mathrm{KI}\left(\mathrm{X}_{2}{ }^{*} \mathrm{X}_{4}\right)$ & 0,00 & 0,00 & 0,23 & 2,36 & 0,02 \\
\hline $\mathrm{CSR}^{*} \mathrm{KI}\left(\mathrm{X}_{3}{ }^{*} \mathrm{X}_{4}\right)$ & 0,00 & 0,00 & 0,02 & 0,25 & 0,80 \\
\hline F count & \multicolumn{4}{|c|}{8,66} & 0,00 \\
\hline Adjusted $R^{2}$ & \multicolumn{5}{|c|}{0,27} \\
\hline
\end{tabular}

Source: data processed (2018).

Based on Table 6 can be seen the results of determination coefficient test with an adjusted value of $\mathrm{R} 2$ of 0.27 this means $27 \%$ variation of firm value influenced by variation of ERM disclosure (X1), disclosure of IC (X2), disclosure of CSR (X3), and institutional ownership $\mathrm{X} 4$ ) as a moderator, the remaining $73 \%$ is influenced by other factors outside the model.

Based on the results of regression analysis in Table 6 it can be seen that the independent variables simultaneously affect the dependent variable shown by the significance value of $F$ at 0.000 is smaller than 0.05 . This means that all independent variables, ERM disclosure (X1), IC disclosure (X2), CSR disclosure (X3), and institutional ownership (X4) as moderators can predict or explain the phenomenon of corporate value at a banking company listed on the BEI from year 2012-2016, so it is concluded that the model in this study worthy to be studied.

Based on Table 6 it can also be seen that institutional ownership ability $(\mathrm{KI})$ moderates the effect of ERM disclosure on firm value indicates a $t$ value of 0.634 with significance of $t$ 0.527 greater than 0.05 . It shows that institutional ownership $(\mathrm{KI})$ does not moderate the effect of ERM disclosure on firm value so it can be deduced that $\mathrm{H} 1$ is rejected. The ability of institutional ownership (KI) to moderate the effect of IC disclosure on firm value shows a $t$ value of 2.358 with a significance of $t 0.020$ smaller than 0.05 . It shows that institutional ownership (KI) moderates the effect of IC disclosure on firm value so it can be deduced that $\mathrm{H} 2$ is accepted. As well as the institutional ownership ability $(\mathrm{KI})$ moderate the influence of 
CSR disclosure on firm value shows $t$ value of 0.252 with significance $t 0.802$ greater than 0.05. It shows that institutional ownership (KI) does not moderate the influence of CSR disclosure on company value so it can be concluded that $\mathrm{H} 3$ is rejected.

\section{CONCLUSION}

Institutional ownership does not moderate the effect of ERM disclosure on the value of a banking firm. The high level of ownership of an enterprise by the institution in the banking sector companies does not affect the extent of ERM disclosure that will be done to increase the value of the company. Institutional ownership moderates positively (reinforces) the influence of IC disclosure on the value of banking firms. High institutional ownership will expand the IC disclosure conducted by companies in the banking sector as a form of voluntary information to stakeholders in order to increase the value of the company. Institutional ownership is able to moderate the influence of CSR disclosure on the value of a banking company. The high level of ownership of an enterprise by the institution in the banking sector does not affect the extent of CSR disclosure that will be done to increase the value of the company.

There are several limitations and suggestions that can be given from the results of this study for further studies. Further research can add other variables considering the value of Adjusted R-squared in this study is only 0.27 or $27 \%$. The suggestion that can be given is that further research can add control variables that theoretically and based on empirical results have been shown to have an effect on firm value, such as firm size. In addition, further research may also attempt to use independent commissioners as a moderating variable of the effect of ERM, IC, and CSR disclosure on firm value.

\section{REFERENCES}

1. Aditya, Oka, dan Prima Naomi. 2017. Penerapan Enterprise Risk Management dan Nilai Perusahaan di Sektor Konstruksi dan Properti. Jurnal Bisnis dan Manajemen, Vol.7 (2): 167-180.

2. Agista, Gissel Glenda, dan Ni Putu Sri Harta Mimba. 2017. Pengaruh Corporate Governance Structure dan Konsentrasi Kepemilikan pada Pengungkapan Enterprise Risk Management. E-Jurnal Akuntansi Universitas Udayana, Vol. 20 (1), hal: 438-466.

3. Agustina, Linda, dan Niswah Baroroh. 2016. The Relationship Between Enterprise Risk Management (ERM) and Firm Value Mediated Through the Financial Performance. Review of Integrative Business and Economics Research, Vol. 5, No. 1, pp.128-138.

4. Ali, Chiraz Ben, Samir Trabelsi, and Mireille Gettler Summa. 2007. Disclosure Quality and Ownership Structure: Evidence from the French Stock Market. The European Accounting Association 2007 conference.

5. Amran, Azlan, A. M. Rosli bin B., and C. H. Modh Hassan. 2009. Risk Reporting: An Exploratory Study on Risk Management Disclosure in Malaysia Annual Reports. Managerial Auditing Journal, Vol. 24, No. 1, Page 39-57.

6. Beasley, Mark, Don Pagach, and Richard Warr. 2008. Information Conveyed in Hiring Announcements of Senior Executives Overseeing Enterprise-Wide Risk Management Processes. Journal of Accounting, Auditing, and Finance.

7. Bertinetti, Giorgio Stefano, Elisa Cavezzali, and Gloria Gardenal. 2013. The Effect of the Enterprise Risk Management Implementation on the Firm Value of European Companies. Working Paper No.10.

8. Bontis, N. 2001. Assessing Knowledge Assets: A Review Of The Models Used To Measurelntellectual Capital. International Journal of Management Reviews, Vol. 3 No. 1, pp. 41-60.

9. Bukh, P.N., Nielsen, C., Gormsen, P., and Mouritsen, J. 2005. Disclosure of information on Intellectual Capital in Danish IPO prospectuses. Accounting, Auditing \& Accountability Journal, Vol. 18, No. 6. pp. 713-732. 
10. Chetty, Sukanya, Rebekah Naidoo and Yudhvir Seetharam. 2015. The Impact of Corporate Social Responsibility on Firms' Financial Performance in South Africa. Contemporary Economics (2)9 pp: 193-214.

11. Devi, Sunitha, I Dewa Nyoman Badera, dan I Gusti Ayu Nyoman Budiasih. 2016. Pengaruh Enterprise Risk Management Disclosure dan Intellectual Capital Disclosure pada Nilai Perusahaan. Simposium Nasional Akuntansi XIX. Lampung.

12. Febriana, Dwiga Ayuning, dan Yeterina Widi Nugrahanti. 2013. Analisis Perbedaan Pengungkapan Intellectual Capital Berdasarkan Struktur Kepemilikan (Studi pada Perusahaan Manufaktur yang Terdaftar di BEI 2011). Journal \& Proceeding Universitas Jenderal Soedirman, Vol.3, No.1.

13. Ghozali, I. (2016), "Aplikasi Analisis Multivariate dengan Program IBM SPSS 23", Badan Penerbitan Universitas Diponegoro: Semarang.

14. Hoyt, Robert E., Dudley L. Moore, and Jr. Chair of InsuranceAndre P. Liebenberg. 2008. The Value Of Enterprise RiskManagement: Evidence From The U.S. Insurance Industry. Journal of Financial and Quantitative Analysis, Vol.26: 519-532.

15. Hoyt, R.E., and Liebenberg, A.P. 2011. The Value of Enterprise Risk Management. Journal of Risk and Insurance, Vol 78 (4): 795-822.

16. Jensen, M.C., and W.H. Meckling. 1976. Theory of The Firm: Managerial Behaviour Agency Cost and Ownership Structure. Journal of Financial Economics. Vol. 3, No. 4: 305-360.

17. Jogiyanto, Hartono. 2000. Teori Portofolio dan Analisis Investasi. Edisi Kedua. Yogyakarta: BPFE UGM.

18. Jo, Hoje, and Maretno A. Harjoto. 2011. Corporate Governance and Firm Value: The Impact of Corporate Social Responsibility. Journal of Business Ethics. Vol. 103. Issue 3, pp: 351-383.

19. Kompas.com. 3 Mei 2011. Inilah 9 Kasus Kejahatan Perbankan. Available from: www.kompas.com. Diakses 23 November 2017.

20. Liana, Lie. 2009. Penggunaan MRA dengan SPSS untuk Menguji Pengaruh Variabel Moderating terhadap Hubungan antara Variabel Independen dan Variabel Dependen. Jurnal Teknologi Informasi Dinamik, 12(2): hal: 90-97.

21. Maulani, Hikmi Fauziah, and Sri Rahayu. 2015. The Influence Of Composition Of Independent Board Of Commissioners, Audit Committee Size, And Company Size Towards Enterprise Risk Management Adoption. E-Proceeding of Management: Vol.2, No.1 April 2015, pp: 349.

22. Meizaroh, dan Jurica Lucyanda. 2011. Pengaruh Corporate Governance dan Konsentrasi Kepemilikan pada Pengungkapan Enterprise Risk Management. Simposium Nasional Akuntansi XIV, hal: 1-30.

23. Mulyasari, Dinda, Miyasto, dan Harjum Muharam. 2016. Pengaruh Enterprise Risk Management, Firm Size, Leverage, Sales Growth, Profitability Terhadap Firm Value (Studi Kasus Pada Perusahaan Sektor Non Keuangan yang Terdaftar di BEI Periode 2011 - 2013). E-Journal Undip.

24. Prayoga, Edo Bangkit dan Luciana Spica Almilia. 2013. Pengaruh Struktur Kepemilikan dan Ukuran Perusahaan Terhadap Pengungkapan Manajemen Risiko. Jurnal Akuntansi \& Keuangan, Vol.4, No.1 hal: 1-19.

25. Sari, Ati Retna, Sutrisno, dan Eko Ganis Sukoharsono. 2013. Pengaruh Kepemilikan Institusional, Komposisi Dewan Komisaris, Kinerja Perusahaan terhadap Luas Pengungkapan Corporate Social Responsibility di dalam Sustainability Report pada Perusahaan Manufaktur yang Terdaftar di BEI. Jurnal Aplikasi Manajemen, Vol. 11, No. 3 , hal: $481-491$

26. Servaes, Henri, and Ane Tamayo. 2013. The Impact of Corporate Social Responsibility on Firm Value: The Role of Customer Awareness. Management Science, Vol. 59, No.5, May 2013, pp: 1045-1061.

27. Singh, Inderpal, and J.-L.W. Mitchell Van der Zahn. 2007. Does Intellectual Capital Disclosure Reduce an IPO's Cost of Capital? The Case of Underpricing. Journal of Intellectual Capital, Vol. 8, No. 3: 178-213. 
28. Sunarsih, Ni Made, dan Ni Putu Yuria Mendra. 2012. Pengaruh Modal Intelektual Terhadap Nilai Perusahaan dengan Kinerja Keuangan Sebagai Variabel Intervening pada Perusahaan yang Terdaftar di Bursa Efek Indonesia. E-Jurnal Akuntansi Unikal.

29. Tahir, Izah Mohd, and Ahmad Rizal Razali. 2011. The Relationship Between Enterprise Risk Management (ERM) and Firm Value: Evidence From Malaysian Public Listed Companies. International Journal of Economics and Management Sciences, Vol.1, No.2, pp: 32-41.

30. Wang, Zhining, Nianxin Wang, and Huigang Liang. 2014. Knowledge Sharing, Intellectual Capital And Firm Performance. Management Decision, Vol.52, No. 2, pp: 230-258.

31. Wibowo, Santoso, Yokhebed, dan Lambok DR Tampubolon. 2016. Pengaruh Pengungkapan CSR dan GCG Terhadap Nilai Perusahaan dengan Kinerja Keuangan Sebagai Variabel Intervening di Perusahaan Manufaktur yang Terdaftar di Bursa Efek Indonesia (2012-2014). Seminar Nasional Multi Disiplin IImu \& Call For Papers Unisbank ke-2. Semarang.

32. Widarjo, Wahyu. 2011. Pengaruh Modal Intelektual dan Pengungkapan Modal Intelektual Pada Nilai Perusahaan. Simposium Nasional Akuntansi XIV. Aceh. 